\title{
Kajian Desentralisasi Fiskal Dan Kesejahteraan Masyarakat Di Provinsi Nusa Tenggara Barat
}

\section{Wira Hendri}

Abstract. Welfare of society was the form big problem and finished yet and we know that of prospirety prom the Human Development Index is conducted in different blooming between regency and provincy especially in NTB the West of Nusa Tenggara and differences arrising is caused presence of potential financial and there were differenced in organizer from each of teritory the potential of financial through fiscal desentralization and organizer of financial was an effective instrument to pushed prospirety of society life to goverment wanted but as we know that is till now occured pro and contra betweet some expert about the importance of function fiscal desetralization and organizer of finncial to developed prospirety of society is still unconsistant or diffrent opinion from experts till now about the relation between variable to show signify the final relation that and it needed comprehensive model to determine of indication variable. So it coud solved the welfare problem between regancy and prosvincy in the west of Nusa (NTB). The purposed of this research is analysed the effect of fiscal desentralization and local financial performance in regency toward the local economy performance, disparity income, and welfare of society especialy in regency area and provincy of Nusa (NTB) and the researched variable is used in this analysis were: fiscal desentralization, the local financial performance, the local economy performance, disparity of income, and welfare of society. The data in this research is used the panel data. And the composite from ten Regency and provincy withtiming distace 2008 - 2017. And this data i got from Department of financial, and statistic center in west of Nusa (NTB) whereas tecnique of data is used by the PLS model. The conclusion from the product analysed were: (1) there were effect of fiscal desentralization positif and significant of local financial performance; (2) fiscal desentralization and local financial performance was positif and significant influential toward local economy performance; (3) fiscal desentralization was negative influential and didn't significant toward disparity income, whereas the local financial performance and the local economy performance was positive influented and significant disparity income; (4) fiscal desentralization was positive influented but it didn't significant of welfare of society, whereas variable of local financial performance, the local economy performance and disparity income in positive imfluenced and significant toward welfare of society; (5) the local financial performance was the full mediation variable from fiscal desentralization toward the local economy performance; (6) the local financial performance is constituted in full mediation variable from fiscal desentalization to disparity income. (7) the local economy performance didn't able to made with full mediation from the local economic performance to disparity income; (8) the local financial performance and disparity income it able to full mediation from fiscal desentralization to welfare of society; (9) the local economy performance and disparity income able with full mediation from fiskal desentralization to welfare of society; (10) disparity income didn't able mediation (non mediation) from local economy performance to welfare of society.

Key Words: Local Financial Performance, Local Economy Performance, Disparity Income, Fiscal Desentralization

\section{Latar Belakang}

Hakekat pembangunan ekonomi adalah mewujudkan kesejahteraan masyarakat yang adil dan makmur sesuai yang diamanatkan oleh UUD 1945. Perwujudan kesejahteraan utamanya dilakukan melalui program pembangunan yang terencana, terpadu dan memiliki perspektif jangka panjang.

Otonomi daerah dilaksanakan dengan memberikan kewenangan yang luas, nyata, dan bertanggungjawab kepada daerah secara proporsional yang diwujudkan dengan pengaturan, pembagian, dan pemanfaatan 
sumberdaya nasional yang berkeadilan serta perimbangan keuangan antara pemerintah pusat dan pemerintahan daerah. Di samping itu, penyelenggaraan otonomi daerah juga dilaksanakan dengan prinsip-prinsip demokrasi, partisipasi masyarakat, pemerataan, dan keadilan, serta memperhatikan potensi dan keanekaragaman daerah. Provinsi merupakan daerah otonom dan sekaligus wilayah administrasi sebagai pelaksana kewenangan pemerintah pusat yang didelegasikan kepada gubernur.

Salah satu provinsi di Indonesia yang menerima otonomi penuh semenjak diberlakukannya kebijakan otonomi daerah pada tahun 2001 adalah Provinsi Nusa Tenggara Barat. Dengan diberlakukannya otonomi daerah, pemerintah akan semakin dekat dengan masyarakatnya sehingga akan lebih mensejahterakan masyarakatnya. Dengan demikian, daerah dapat meningkatkan kesejahteraan masyarakat melalui peningkatan pembangunan manusia yang tercermin dari Angka Indeks Pembangunan Manusia (IPM) yang meningkat. Paradigma pembangunan menempatkan manusia (penduduk) sebagai fokus dan sasaran akhir dari seluruh kegiatan pembangunan, yaitu tercapainya penguasaan atas sumber daya, peningkatan derajat kesehatan dan peningkatan pendidikan. Selama tahun 2012 2017 perkembangan IPM di Kabupaten/Kota di provinsi Nusa Tenggara Barat terus mengalami peningkatan seperti yang disajikan pada Tabel 1.1.

Tabel 1.1

Indeks Pembangunan Manusia (IPM) di Kabupaten/Kota di Provinsi Nusa Tenggara Barat Dan Nasional Tahun 2012 - 2017 (dalam Persen)

\begin{tabular}{|c|l|c|c|c|c|c|c|c|}
\hline No & Kabupaten/Kota & 2012 & 2013 & 2014 & 2015 & 2016 & 2017 & $\begin{array}{c}\text { Rata- } \\
\text { rata }\end{array}$ \\
\hline 1 & Lombok Barat & 62,24 & 62,91 & 63,52 & 64,62 & 65,55 & 66,37 & 64,20 \\
\hline 2 & Lombok Tengah & 60,57 & 61,25 & 61,88 & 62,74 & 63,22 & 64,36 & 62,34 \\
\hline 3 & Lombok Timur & 60,73 & 61,43 & 62,07 & 62,83 & 63,70 & 64,37 & 62,52 \\
\hline 4 & Sumbawa & 61,96 & 62,44 & 62,88 & 63,91 & 64,89 & 65,84 & 63,65 \\
\hline 5 & Dompu & 62,60 & 63,16 & 63,53 & 64,56 & 65,48 & 66,33 & 64,28 \\
\hline 6 & Bima & 61,05 & 62,08 & 62,61 & 63,48 & 64,15 & 65,01 & 63,06 \\
\hline 7 & Sumbawa Barat & 66,45 & 66,86 & 67,19 & 68,38 & 69,26 & 70,08 & 68,04 \\
\hline 8 & Lombok Utara & 58,19 & 59,20 & 60,17 & 61,15 & 62,24 & 63,04 & 60,67 \\
\hline 9 & Kota Mataram & $\mathbf{7 4 , 2 2}$ & $\mathbf{7 5 , 2 2}$ & $\mathbf{7 5 , 9 3}$ & $\mathbf{7 6 , 3 7}$ & $\mathbf{7 7 , 2 0}$ & $\mathbf{7 7 , 8 4}$ & 76,13 \\
\hline 10 & Kota Bima & $\mathbf{7 1 , 2 1}$ & $\mathbf{7 1 , 7 2}$ & $\mathbf{7 2 , 2 3}$ & $\mathbf{7 2 , 9 9}$ & $\mathbf{7 3 , 6 7}$ & $\mathbf{7 4 , 3 6}$ & 72,70 \\
\hline \multirow{2}{*}{} & NTB & $\mathbf{6 2 , 9 8}$ & $\mathbf{6 3 , 7 6}$ & $\mathbf{6 4 , 3 1}$ & $\mathbf{6 5 , 1 9}$ & $\mathbf{6 5 , 8 1}$ & $\mathbf{6 6 , 5 8}$ & $\mathbf{6 4 , 7 7}$ \\
\hline & Nasional & $\mathbf{6 7 , 7 0}$ & $\mathbf{6 8 , 3 1}$ & $\mathbf{6 8 , 9 0}$ & $\mathbf{6 9 , 5 5}$ & $\mathbf{7 0 , 1 8}$ & $\mathbf{7 0 , 8 1}$ & $\mathbf{6 9 , 2 4}$ \\
\hline
\end{tabular}

Sumber: Badan Pusat Statistik Provinsi NTB, Tahun 2018 (Diolah)
Berdasarkan Tabel 1.1 di atas dapat dilihat bahwa secara rata-rata IPM di provinsi Nusa Tenggara Barat berada di bawah ratarata IPM secara nasional. Hal ini terjadi karna masih belum efektif dan meratanya alokasi pembangunan pada setiap daerah. meskipun berada di bawah rata-rata nasional, IPM di provinsi Nusa Tenggara Barat mengalami trend peningkatan dari 62,98 persen pada tahun 2012 menjadi 64,77 persen pada tahun 2017. Daerah yang memiliki IPM paling tinggi adalah Kota Mataram dengan indeks rata-rata 76,13 persen, sementara yaang terendah adalah Kabupaten Lombok Utara dengan indeks sebesar 60,67 persen. Dari Tabel 1.1 dapat dilihat pula bahwa tingkat kesejahteraan masyarakat berdasarkan IPM di wilayah Kabupaten/Kota agak timpang demikian pula Jika dilihat dari perkembangan per Provinsi juga menunjukkan hal yang sama. IPM NTB berada pada urutan keenam terendah dari 34 Provinsi yang ada di Indonesia.

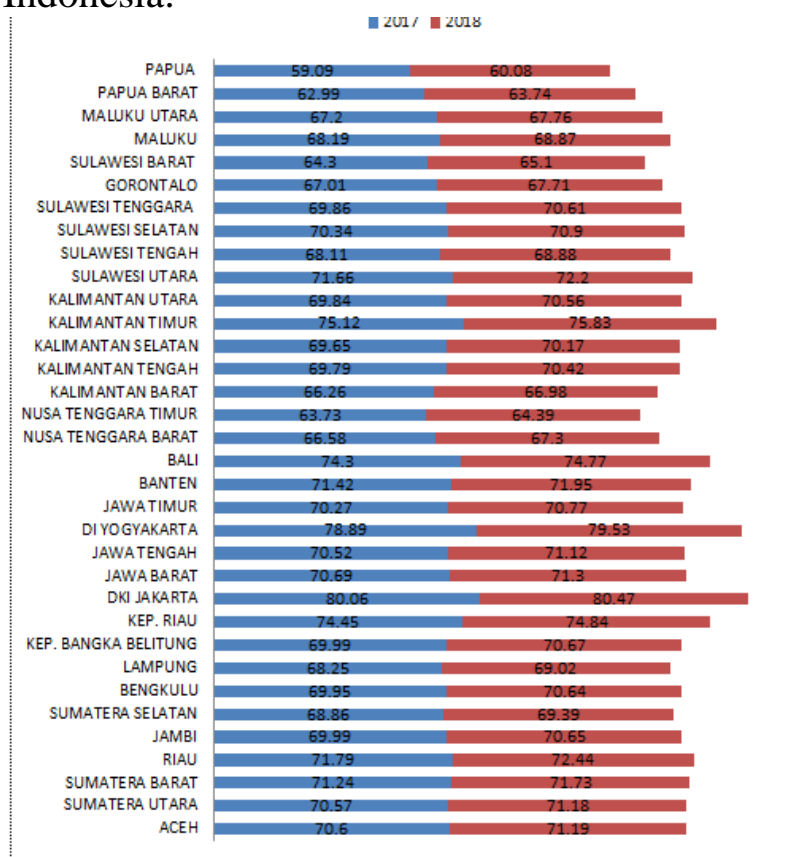

Gambar 1.1

Indeks Pembangunan Manusia (IPM)

Menurut Provinsi Tahun 2017 - 2018

Sumber: Badan Pusat Statistik, 2018

Berdasarkan Gambar 1.1 IPM Provinsi Nusa Tenggara Barat berada pada posisi keenam terendah setelah Kalimantan Barat, Kalimantan Utara, Nusa tenggara Timur, Sulawesi Selatan dan Sulawesi Tenggara dari 34 provinsi yang ada. Rendahnya IPM 
tersebut berasal dari indikator pendidikan yang mencakup angka melek huruf dan ratarata lama sekolah penduduk usia 15 tahun ke atas serta indikator kesehatan yang diproksi dengan usia harapan hidup yang masih rendah. Angka melek huruf penduduk Nusa Tenggara Barat pada tahun 2018 tercatat 81,05 persen, jauh di bawah angka rata-rata nasional $(92,91$ persen) dan rata-rata lama sekolah pada tahun yang sama baru mencapai 6,77 tahun dibandingkan angka nasional (7,92 tahun) pada tahun 2018. Selain itu, usia harapan hidup juga menjadi penyebab utama rendahnya IPM tersebut. Pada tahun 2017, usia harapan hidup penduduk Nusa Tenggara Barat adalah 62,1 tahun, jauh lebih rendah dibandingkan rata-rata nasional yakni 69,4 tahun. Di lain pihak, faktor ekonomi berupa kemampuan daya beli diproksi dengan pengeluaran per-kapita yang disesuaikan menunjukkan Nusa Tenggara Barat lebih tinggi dibandingkan rata-rata nasional yakni Rp. 639,89 berbanding Rp. 633,64. Hal ini dapat mengesankan bahwa kemampuan daya beli yang cukup tinggi tidak mampu digerakkan untuk memperoleh pendidikan dan kesehatan yang memadai (BPS, 2018).

Beberapa faktor yang menyebabkan perbedaan kesejahteraan masyarakat diberbagai daerah yang dicerminkan oleh perbedaan IPM adalah perbedaan potensi yang dimiliki daerah tersebut. Kalau dikaitkan dengan pelaksanaan otonomi daerah. Ciri utama yang menunjukkan suatu daerah otonom mampu berotonomi terletak pada potensi keuangan atau desentralisasi fiskal dan pengelolaan atau kinerja keuangannya. Artinya, desentralisasi fiskal dan kinerja keuangan yang bagus akan berdampak terhadap kualitas kinerja ekonomi daerah. Kinerja keuangan daerah menurut Halim (2001) dapat dilihat dari: efektivitas, efisiensi, kemandirian keuangan, keserasiannya dan upaya pemungutan Pendapatan Asli Daerah (PAD). Di lain pihak, kinerja ekonomi dapat dilihat dari pertumbuhan ekonomi, inflasi, pengangguran dan kemiskinan. Dengan adanya kinerja ekonomi yang baik menyebabkan kesejahteraan masyarakat meningkat.
Adanya hubungan tersebut mendorong para ahli melakukan penelitian antara lain Oates (1993); Bird (1993); Bird, Ebel, dan Wallich (1995); Bahl dan Linh (1992) dan Gramlich (1993) mengatakan bahwa dengan diserahkannya beberapa kewenangan kepada pemerintah daerah, diharapkan pelayanan masyarakat semakin efisien dan pada gilirannya akan mendorong pertumbuhan ekonomi. Kemudian juga dipertegas oleh penelitian oleh Prud'homme (1995), Peterson (1996), Zang dan Zao (1998) mengatakan terdapat pengaruh positif desentralisasi fiskal terhadap pertumbuhan ekonomi daerah.

Namun demikian, World Bank (1997), Martinez dan NcNab (2001) mengingatkan bahwa desentralisasi fiskal dapat juga berdampak negatif terhadap pertumbuhan ekonomi. Desentralisasi fiskal dapat mendorong kearah ketidakstabilan ekonomi makro yang pada gilirannya akan menghambat pertumbuhan ekonomi sebab desentralisasi fiskal dapat mengurangi pengeluaran pemerintah dan pajak yang berbasis pada pemerintah pusat yang dapat digunakan untuk melakukan fungsi stabilisasi. Kemudian juga dipertegas oleh beberapa penelitian diantaranya, Philips dan Woller (1998), Davodi dan Zao (1998) untuk negaranegara berkembang, serta Zang dan Zao (2001) dalam penelitiannya di cina. Dan di Indonesia oleh Swasono (Simanjuntak, 2010).

Terlepas dari hasil studi tentang pengaruh desentralisasi fiskal terhadap kinerja ekonomi yang beragam tersebut, pendapat dan argumentasi bahwa desentralisasi fiskal dapat meningkatkan efisiensi yang selanjutnya akan mendorong kesejahteraan masyarakat cendrung diterima secara luas. Hal ini ditunjukkan dari implementasi desentralisasi fiskal yang semakin berkembang diberbagai negara, pengamatan terkini sebagaimana dikemukakan Robert (2010) menunjukkan bahwa 63 dari 75 negara berkembangan dan transisional telah dan sedang melakukan desentralisasi fiskal, termasuk didalamnya adalah Indonesia. Hal tersebut menyiratkan harapan dari negaranegara tersebut bahwa dengan implementasi desentralisasi fiskal akan dapat terwujud 
efisiensi ekonomi yang dapat meningkatkan kesejahteraan masyarakat.

Sampai saat ini masih terjadi pro dan kontra dari para ahli mengenai pentingnya peranan desentralisasi fiskal dan pengelolaan keuangan dalam mendorong kesejahteraan masyarakat sehingga terdapat ketidak konsistenan dari para ahli terhadap arah hubungan antar variabel yang menandakan belum berakhirnya arah hubungan tersebut. Dibutuhkan suatu model yang kompeherensif dalam menentukan arah hubungan antar variabel sehingga dapat memecahkan masalah perbedaan kesejahteraan masyarakat antar daerah Kabupaten/Kota di Provinsi Nusa Tenggara Barat.

\section{TINJAUAN PUSTAKA \\ Kesejahteraan Masyarakat}

Kesejahteraan dalam artian yang sangat luas mencakup berbagai tindakan yang dilakukan manusia untuk mencapai taraf hidup yang lebih baik, taraf hidup yang lebih baik ini tidak hanya diukur secara ekonomi dan fisik belaka, tapi juga ikut memperhatikan aspek sosial, mental dan segi kehidupan spiritual. Kesejahteraan sosial dapat diartikan sebagai kondisi sejahtera dari suatu masyarakat, kesejahteraan sosial pada umumnya meliputi kesehatan, keadaan ekonomi, kebahagiaan dan kualitas hidup rakyat. Di Indonesia kesejahteraan sosial dijamin oleh UUD 1945 pasal 33 dan pasal 34. Dalam UUD 1945 jelas disebutkan bahwa kemakmuran rakyat yang lebih diutamakan dari pada kemakmuran perseorangan, fakir miskin dan anak-anak terlantar dipelihara oleh negara. Namun pada kenyataannya hingga saat ini masih banyak rakyat Indonesia yang hidup di bawah garis kemiskinan dan terlantar tidak mendapatkan perhatian.

Indikator kesejahteraan masyarakat yang hanya didasarkan pada Produk Domestik Bruto merupakan cara pandang yang terlalu sederhana dalam memahami kesejahteraan masyarakat. Oleh karena itu, pengembangan model yang berkaitan dengan kesejahteraan masyarakat dilakukan dengan memasukkan aspek harga lokal ke dalam Produk Domestik Bruto (PDRB) sehingga menjadi purchasing power adjusted real Produk Domestik Bruto. Formulasi Produk Domestik Bruto (PDRB) per-kapita dengan memperhitungkan daya beli mengakibatkan Produk Domestik Bruto (PDB) suatu wilayah menjadi lebih obyektif jika dibandingkan dengan Produk Domestik Bruto wilayah lain, namun tetap saja bahwa transformasi indikator Produk Domestik Bruto per-kapita berdasarkan daya beli tetaplah dianggap subyektif karena ukuran tingkat kesejahteraan masyarakat menjadi sangat ekonomi dan kuantitatif. Hal inilah yang kemudian memunculkan ukuran-ukuran yang baru mengenai indikator kesejahteraan masyarakat sebagai ukuran keberhasilan pembangunan.

Teori kesejahteraan diklasifikasikan menjadi tiga, yaitu classical utilitarian, neoclassical welfare theory, dan new contractarian approach. Classical utilitarian menekankan bahwa kepuasaan atau kesenangan seseorang dapat diukur dan bertambah. Tingkat kepuasan setiap individu dapat dibandingkan secara kuantitatif. Neoclassical welfare menekankan pada prinsip pareto optimality. Pareto optimum didefinisikan sebagai sebuah posisi di mana tidak memungkinkan suatu relokasi input atau output untuk membuat seseorang menjadi lebih baik tanpa menyebabkan sedikitnya satu orang lebih buruk. New contractarian approach menekankan pada konsep dimana setiap individu memiliki kebebasan maksimum dalam hidupnya. Ketiga pandangan tersebut menekankan bahwa tingkat kesejahteraan seseorang sangat tergantung pada tingkat kepuasaan dan kesenangan yang diraih dalam kehidupannnya.

United Nations Development Program (UNDP) mengenalkan formula Human Development Index (HDI) atau disebut pula dengan Indeks Pembangunan Manusia (IPM) pada tahun 1990. Indeks Pembangunan Manusia (IPM) dapat digunakan untuk mengklasifikasikan apakah sebuah negara/daerah merupakan negara/daerah maju, berkembang, atau terbelakang dan juga untuk mengukur pengaruh kebijaksanaan ekonomi terhadap kualitas hidup.

\section{Desentralisasi Fiskal}

Desentralisasi fiskal berarti pelimpahan kewenangan di bidang penerimaan yang 
sebelumnya tersentralisasi baik secara administratif dan pemanfaatannya diatur atau dilakukan oleh pemerintah pusat (Elmi, 2003). Setidaknya terdapat empat agen yang berperan penting dalam desentralisasi fiskal, yaitu: pemerintah pusat, unit-unit administratif lokal, pemerintah daerah, dan penduduk setempat atau entitas politik.

Oates (1993), menjelaskan tentang Fiscal Decentralization and Economic Development yang dilaksanakan di 58 negara dengan hasil bahwa sentralisasi fiskal berhubungan negatif dan signifikan terhadap tingkat pendapatan per-kapita. Bhal (1999) menjelaskan bahwa keberhasilan desentralisasi fiskal di suatu wilayah ditentukan oleh 12 ketentuan peraturan, yaitu desentralisasi fiskal harus dipandang sebagai sebuah sistem yang komprehensif, desentralisasi fiskal harus diikuti dengan desentralisasi keuangan, pemerintah pusat harus mempunyai kekuatan untuk memonitor dan mengevaluasi implementasi desentralisasi fiskal.

\section{Kinerja Keuangan Daerah}

Kinerja Keuangan Daerah adalah kemampuan suatu daerah untuk menggali dan mengelola sumber-sumber keuangan asli daerah dalam memenuhi kebutuhannya guna mendukung berjalannya sistem pemerintahan, pelayanan kepada masyarakat dan pembangunan daerahnya dengan tidak tergantung sepenuhnya kepada pemerintah pusat dan mempunyai keleluasaan di dalam menggunakan dana-dana untuk kepentingan masyarakat daerah dalam batas-batas yang ditentukan peraturan perundang-undangan (Syamsi, 1986).

\section{Pemerintah Daerah sebagai pihak} yang diberikan tugas menjalankan pemerintahan, pembangunan dan pelayanan masyarakat wajib melaporkan pertanggungjawaban keuangan atas sumber daya yang dihimpun dari masyarakat sebagai dasar penilaian kinerja keuangannya. Salah satu alat untuk menganalisis Kinerja Keuangan Pemerintah Daerah dalam mengelola keuangan daerahnya adalah dengan melakukan analisis keuangan terhadap APBD yang telah ditetapkan dan dilaksanakannya (Halim, 2007).
Dengan demikian setiap Pemerintah Daerah untuk mengukur Kinerja Keuangan Daerahnya menggunakan beberapa Rasio Kinerja Keuangan Daerah yang antara lain: Rasio Drajat Desentralisasi Fiskal, Rasio Kemandirian Keuangan Dearah, Rasio Efektivitas Pendapatan Asli Daerah (PAD), Rasio Efisiensi Keuangan Daerah, Rasio Keserasian, Upaya Fiskal dan Rasio Pertumbuhan

\section{Kinerja Ekonomi Daerah}

Kinerja Ekonomi diartikan sebagai gambaran bagus tidaknya perekonomian suatu daerah. Variabel - variabel yang dapat memperlihatkannya adalah variabel Produk Domestik Regional Bruto (PDRB), inflasi, pengangguran, tenaga kerja dan kependudukan, (Kuncoro, 2003). Menurut McEachern (2000) untuk mengukur kinerja ekonomi pada suatu wilayah dapat dilakukan dengan berbagai cara, antara lain dengan melihat jumlah pekerja, rata-rata penghasilan, jumlah produksi, jumlah dan ukuran perusahaan. Disamping itu, ukuran kinerja perekonomian yang sering diperhatikan untuk mengetahui kemajuan ekonomi suatu wilayah atau negara adalah pertumbuhan ekonomi dan tenaga kerja, produktivitas, standar hidup, pengangguran, inflasi, tabungan dan formulasi modal, serta variabel lainnya.

\section{Ketimpangan Pendapatan}

Kesenjangan pendapatan dapat diartikan sebagai perbedaan kemakmuran ekonomi antara yang kaya dengan yang miskin. Hal ini tercermin dari perbedaan pendapatan (Robert E Baldwin, 1986). Masalah kesenjangan pendapatan sering juga diikhtisarkan, bahwa pendapatan riil dari yang kaya terus bertambah sedangkan yang miskin terus berkurang. Ini berarti bahwa pendapatan riil dari yang kaya tumbuh lebih cepat dari pada yang miskin (Bruce Herrick/Charles $\mathrm{P}$ Kindleberger, 1988).

Secara teoritik, kesenjangan ekonomi antarwilayah dapat dijelaskan menggunakan Hipotesis Neoklasik. Penganut Hipotesis Neoklasik menyatakan pada permulaan proses pembangunan suatu negara, kesenjangan ekonomi antarwilayah cenderung meningkat. Proses ini akan terjadi sampai kesenjangan tersebut mencapai titik puncak. 
Bila proses pembangunan berlanjut, maka secara berangsur-angsur kesenjangan ekonomi antar wilayah akan menurun. Hal tersebut dikarenakan pada waktu proses pembangunan baru dimulai di NSB, peluang pembangunan yang ada umumnya dimanfaatkan oleh daerah-daerah yang kondisi pembangunan sudah lebih baik. Sedang daerah yang tertinggal tidak mampu memanfaatkan peluang ini karena keterbatasan sarana dan prasarana serta rendahnya kualitas SDM karena pertumbuhan ekonomi lebih cepat di daerah dengan kondisinya lebih baik, sedangkan daerah yang terbelakang tidak banyak mengalami kemajuan maka kesenjangan ekonomi antarwilayah cenderung meningkat.

\section{Kerangka Konsep}

Berdasarkan kerangka berfikir diatas, maka hubungan antar variabel penelitian ditunjukkan pada Gambar 2 berikut.

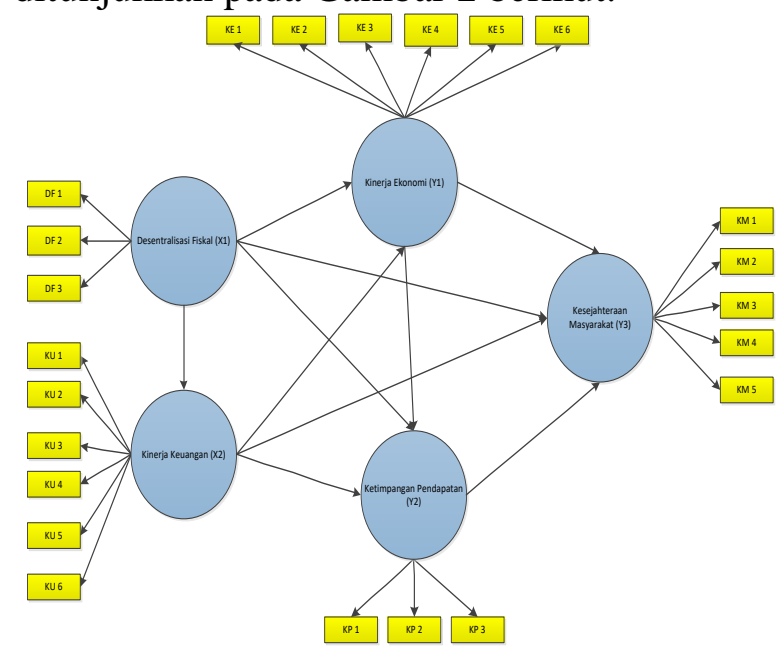

Gambar 2. Kerangka Konsep Penelitian

\section{METODE PENELITIAN \\ Rancangan Penelitian}

Rancangan penelitian (research design)

Kajian Desentralisasi Fiskal dan

Kesejahteraan Masyarakat di Provinsi Nusa Tenggara Barat diarahkan untuk memecahkan pokok masalah, tujuan dan hipotesis yang diajukan. Dalam penelitian ini pendekatan yang digunakan adalah penelitian kuantitatif dengan tingkat eksplanasi assosiatif dengan pengukuran statistik yang didukung data sekunder dengan dimensi waktu menggunakan data panel (Pooled data) yaitu kombinasi dari pengamatan cross section sebanyak 10 Kabupaten/Kota di Provinsi Nusa Tenggara Barat dan time series selama
10 tahun periode 2008 - 2017. pendekatan tingkat Eksplanasi assosiatif mencoba mencari kejelasan tentang fenomena atau hubungan antar satu variabel dengan variabel lain dengan menggunakan data kuantitatif. Teknik pengumpulan data yang digunakan observasi melalui studi pustaka, wawancara mendalam baik secara langsung maupun tidak langsung dan dokumentasi.

\section{Lokasi Penelitian}

Lokasi penelitian dilaksanakan di Provinsi Nusa Tenggara Barat sebagai salah satu provinsi dari ke 33 provinsi di Indonesia seperti peta yang ditunjukkan pada gambar 4.1. secara administrasi provinsi Nusa Tenggara Barat mencakup 10 Kabupaten/Kota yang terdiri dari: 1) Kabupaten Lombok Timur; 2) Kabupaten Lombok Tengah; 3) Kabupaten Lombok Barat; 4) Kabupaten Lombok Utara; 5) Kabupaten Sumbawa; 6) Kabupaten Sumbawa Barat; 7) Kabupaten Bima; 8) Kota Bima; 9) Kota Mataram; 10) Kabupaten Dompu.

Pemilihan Provinsi Nusa Tenggara Barat sebagai lokasi penelitian di landasi beberapa pertimbangan. Pertama, pasca reformasi perkembangan pemerintahan Provinsi Nusa Tenggara Barat sampai saat pengamatan ini telah terbentuk menjadi 10 Kabupaten/Kota secara definitif. Namun masih tercatat memiliki persentase angka kemiskinan relatif tinggi (BPS 2016); kedua, Provinsi Nusa Tenggara Barat memiliki kekayaan sumber daya alam melimpah, namun yang baru di kelola secara menonjol pada sektor pertanian, pertambangan dan pariwisata yang berkontribusi relatif besar dalam struktur ekonomi daerah; ketiga, pertumbuhan ekonomi antar wilayah yang tidak merata akibat terkonsetrasinya pembangunan pada bagian Kabupaten/Kota yang berada di wilayah pusat kota; kelima, adanya sebaran penduduk tidak merata antar Kabupaten/Kota dimana Kabupaten/Kota yang berada di pulau Lombok lebih besar jumlah penduduknya dibandingkan Kabupaten/Kota yang berada di wilayah Sumbawa; keenam, penelitian ilmiah seperti ini sangat sedikit dilakukan di provinsi Nusa Tenggara Barat oleh peneliti sebelumnya. 


\section{Teknik Analisa Data}

Teknik analisis data dalam penelitian ini menggunakan pendekatan Partial Least Square (PLS). PLS merupakan model SEM yang berbasis komponen atau varian. Adapun langkah-langkah permodelan persamaan struktural berbasis PLS dengan software Smart-PLS, yaitu: (1) merancang model struktural; (2) merancang model pengukuran (outer model); (3) menkonstruksi diagram jalur; (4) konversi diagram jalur ke dalam sistem persamaan untuk outer model; (5) estimasi; (6) pengujian Goodness of Fit Model; dan (7) pengujian hipotesis.

\section{HASIL PENELITIAN \\ Model Persamaan Struktural \\ Uji Outer Model}

Untuk mengetahui apakah indikator yang digunakan untuk membentuk konstruk atau variabel latent dalam penelitian adalah valid, maka dilakukan analisis sebagai berikut.

\section{1) Convergent Validity}

Hampir semua indikator yang membentuk konstruk eksogen (reflektif), yaitu: Desentralisasi fiskal, Kinerja Keuangan, Kinerja Ekonomi dan Ketimpangan Pendapatan memiliki nilai outer loading diatas 0,50 dan secara statistik adalah signifikan dengan nilai t-hitung lebih besar dari 1,96. Hal ini berarti terpenuhi syarat convergent validity, kecuali untuk indikator KE3 (Penyerapan Tenaga Kerja) terhadap konstruk Kinerja Ekonomi.

Indikator tersebut memiliki nilai outer loading lebih kecil dari 0,50 dan nilai t-hitung lebih kecil dari 1,96, sebagai tindak lanjut hal tersebut maka KE3 harus di drop.

\section{2) Discriminant Validity}

Untuk mengetahui validitas suatu konstruk juga dapat dilihat dari discriminant validity. Discriminant validity pada indikator reflektif adalah dengan melihat cross loading indikator terhadap konstruk atau latennya. Hasil analisis data menunjukkan bahwa discriminant validity sudah terpenuhi dengan melihat cross loading yang sudah terpenuhi dengan baik, karena indikatornya memiliki cross loading pada konstruknya lebih tinggi dibandingkan terhadap konstruk lainnya.
Kelayakan konstruk yang dibuat juga dapat dilihat dari discrimant validity melalui Average Variance Extracted (AVE), diketahui bahwa konstruk desentralisasi fiskal, kinerja keuangan, kinerja ekonomi, ketimpangan pendapatan dan kesejahteraan masyarakat memiliki nilai AVE diatas 0,50 sehingga dikatakan baik.

\section{Uji Inner Model}

Uji inner model merupakan pengujian antar variabel dengan melihat nilai $R$-Square dan $\mathrm{Q}^{2}$ atau Stone Geiser $Q$ Square test. Konstruk dengan melihat pengaruh signifikan antar konstruk yang diuji.

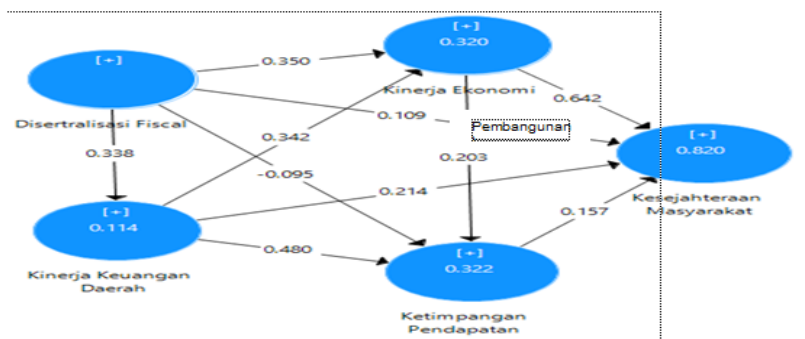

Gambar 3. Diagram Jalur Inner Model

Model struktural dalam PLS perlu dievaluasi dengan menggunakan $R$-square untuk variabel dependen dan nilai signifikansinya berdasarkan nilai $t$-values pada setiap path. Tabel 1. menunjukkan nilai $R$-square untuk setiap variabel endogen.

Tabel 1. Nilai $R$ Square untuk Variabel Konstruk Endogen

\begin{tabular}{|l|l:l|}
\hline \multicolumn{1}{|c}{ Variabel } & R-square & Keterangan \\
\hline Kinerja Keuangan $\left(\mathrm{X}_{2}\right)$ & 0,114 & Lemah \\
Kinerja Ekonomi $\left(\mathrm{Y}_{1}\right)$ & 0,320 & Lemah \\
Ketimpangan Pendapatan $\left(\mathrm{Y}_{2}\right)$ & 0,322 & Lemah \\
Kesejahteraan Masyarakat $\left(\mathrm{Y}_{3}\right)$ & 0,820 & Kuat \\
\hline
\end{tabular}

Berdasarkan $\mathrm{R}^{2}$ pada Tabel 2. diperoleh nilai $\mathrm{Q}^{2}$ sebesar 0,930 , dapat diartikan bahwa 93 persen variasi dari variasi dalam kesejahteraan masyarakat di jelaskan oleh variabel desentralisasi fiskal, kinerja keuangan, kinerja ekonomi dan ketimpangan pendapatan.

\section{Pengaruh Langsung, Pengaruh Tidak Langsung, dan Pengaruh Total}

Untuk mengetahui pengaruh langsung antarvariabel konstruk dapat dilihat dari hasil analisis nilai path coefficients yang ditampilkan pada Tabel 2.

Tabel 2. Path Coefisient Desentralisasi Fiskal (X1), Kinerja Keuangan Daerah (X2), Kinerja 
Ekonomi (Y1), Ketimpangan Pendapatan (Y2) dan Kesejahteraan Masyarakat (Y3)

\begin{tabular}{|c|c|c|c|c|}
\hline $\begin{array}{c}\text { Hubungan antar } \\
\text { variabel }\end{array}$ & $\begin{array}{c}\text { Original } \\
\text { sampel }\end{array}$ & $\begin{array}{c}\text { Standard } \\
\text { Deviation }\end{array}$ & T statistik & P values \\
\hline $\mathrm{X} 1 \rightarrow$ Y3 & 0,109 & 0,057 & 1,900 & 0,058 \\
$\mathrm{X} 1 \rightarrow$ Y2 & $-0,095$ & 0,084 & 1,136 & 0,257 \\
$\mathrm{X} 1 \rightarrow$ Y1 & 0,350 & 0,096 & 3,628 & 0,000 \\
$\mathrm{X} 1 \rightarrow \mathrm{X} 2$ & 0,338 & 0,113 & 3,003 & 0,003 \\
$\mathrm{Y} 2 \rightarrow$ Y3 & 0,157 & 0,055 & 2,858 & 0,004 \\
$\mathrm{Y} 1 \rightarrow$ Y3 & 0,642 & 0,055 & 11,63 & 0,000 \\
$\mathrm{Y} 1 \rightarrow$ Y2 & 0,203 & 0,087 & 2,339 & 0,020 \\
$\mathrm{X} 2 \rightarrow$ Y3 & 0,214 & 0,053 & 4,033 & 0,000 \\
$\mathrm{X} 2 \rightarrow$ Y2 & 0,480 & 0,075 & 6,370 & 0,000 \\
$\mathrm{X} 2 \rightarrow$ Y1 & 0,342 & 0,093 & 3,680 & 0,000 \\
\hline
\end{tabular}

Berdasarkan Tabel 2 diatas diketahui bahwa desentralisasi fiskal berpengaruh positif dan signifikan terhadap kinerja keuangan daerah dan kinerja ekonomi. Namun, tidak berpengaruh signifikan terhadap ketimpangan pendapatan dan kesejahteraan masyarakat. Kinerja keuangan berpengaruh positif dan signifikan terhadap kinerja ekonomi, ketimpangan pendapatan dan kesejahteraan masyarakat. Kinerja ekonomi berpengaruh positif dan signifikan terhadap ketimpangan pendapatan dan kesejahteraan masyarakat. Demikian juga Ketimpangan pendapatan berpengaruh positif dan signifikan terhadap kesejahteraan masyarakat.

Untuk mengetahui pengaruh tidak langsung antarvariabel konstruk dapat dilihat dari hasil analisis nilai Indirect Effect yang ditampilkan pada Tabel 3.

Tabel 3. Nilai Indirect Effect Desentralisasi Fiskal (X1), Kinerja Keuangan Daerah (X2), Kinerja Ekonomi (Y1), Ketimpangan Pendapatan (Y2) dan Kesejahteraan Masyarakat (Y3)

\begin{tabular}{|c|c|c|c|c|c|c|}
\hline \multicolumn{2}{|c|}{ Konstruk } & $\begin{array}{l}\text { Original } \\
\text { Sample }\end{array}$ & $\begin{array}{l}\text { Standar } \\
\text { Error }\end{array}$ & T Statistic & P Values & Ket. \\
\hline $\mathrm{X} 1$ & $\rightarrow \mathrm{Y} 3$ & 0,396 & 0,087 & 4,549 & 0,000 & Mediasi Penuh \\
\hline $\mathrm{X} 1$ & $\rightarrow \mathrm{Y} 2$ & 0,257 & 0,050 & 3,421 & 0,001 & Mediasi Penuh \\
\hline $\mathrm{X} 2$ & $\rightarrow \mathrm{Y} 1$ & 0,116 & 0,050 & 2,328 & 0,020 & Mediasi Penuh \\
\hline Y1 & $\rightarrow \mathrm{Y} 3$ & 0,032 & 0,020 & 1,568 & 0,119 & Non Mediasi \\
\hline $\mathrm{x} 2$ & $\rightarrow \mathrm{Y} 3$ & 0,306 & 0,072 & 4,242 & 0,000 & Mediasi Penuh \\
\hline $\mathrm{X} 2$ & $\rightarrow \mathrm{Y} 2$ & 0,069 & 0,040 & 1,735 & 0,083 & Non Mediasi \\
\hline
\end{tabular}

Ket $=*$ )Signifikan pada $\alpha=5 \%$

Berdasarkan Tabel 2 dan Tabel 3 dapat dihitung pengaruh langsung, pengaruh tidak langsung dan pengaruh total antarvariabel dalam penelitian ini, yaitu desentralisasi fiskal $\left(\mathrm{X}_{1}\right)$, kinerja keuangan $\left(\mathrm{X}_{2}\right)$, kinerja Ekonomi $\left(\mathrm{Y}_{1}\right)$, ketimpangan pendapatan $\left(\mathrm{Y}_{2}\right)$ dan Kesejahteraan Masyarakat $\left(\mathrm{Y}_{3}\right)$. Penghitungan pengaruh langsung, pengaruh tidak langsung dan pengaruh total disarikan dan disajikan pada Tabel 5.32.

Tabel 4 Ringkasan Pengaruh Langsung, Pengaruh Tidak Langsung, dan Pengaruh Total Antarvariabel Penelitian

\begin{tabular}{|l|c|c|c|}
\hline \multirow{2}{*}{ Kontruk Dependen } & \multicolumn{3}{|c|}{ Kontruk Independen } \\
\cline { 2 - 4 } & $\begin{array}{c}\text { Kinerja } \\
\text { Ekonomi } \\
\left(\mathrm{Y}_{1}\right)\end{array}$ & $\begin{array}{c}\text { Ketimpangan } \\
\text { Pendapatan } \\
\left(\mathrm{Y}_{2}\right)\end{array}$ & $\begin{array}{c}\text { Kesejahteraan } \\
\text { Masyarakat } \\
\left(\mathrm{Y}_{3}\right)\end{array}$ \\
\hline Desentralisasi Fiskal & & & \\
- - Pengaruh Langsung & 0,350 & $-0,095$ & 0,109 \\
- Pengaruh Tidak Langsung & 0,116 & 0,256 & 0,396 \\
- Pengaruh Total & 0,446 & 0,162 & 0,505 \\
\hline Kinerja Keuangan Daerah & & & \\
- PengaruhLangsung & 0,304 & 0,480 & 0,214 \\
- - Pengaruh tidak langsung & - & 0,069 & 0,306 \\
- Pengaruh Total & 0,304 & 0,550 & 0,520 \\
\hline Kinerja Ekonomi & & & \\
- PengaruhLangsung & - & 0,209 & 0,642 \\
- - Pengaruh Tidak Langsung & - & - & 0,032 \\
\hline - Pengaruh Total & - & 0,209 & 0,674 \\
\hline
\end{tabular}

\section{PEMBAHASAN}

\section{Pengaruh Desentralisasi Fiskal Terhadap Kinerja Keuangan Daerah}

Hasil penelitian ini menunjukkan bahwa desentralisasi fiskal berpengaruh positif dan signifikan terhadap kinerja keuangan daerah. Dengan demikian, desentralisasi fiskal yang diukur menggunakan indikator pengeluaran, indikator pendapatan dan indikator otonomi mampu menjelaskan dengan baik perkembangan kinerja keuangan daerah yang diukur menggunakan rasio kemandirian, rasio efektivitas PAD, upaya fiskal dan pertumbuhan pendapatan daerah. Hasil studi ini mendukung hipotesis pertama yaitu desentralisasi fiskal berpengaruh positif dan signifikan terhadap kinerja keuangan daerah. Hal ini menunjukkan bahwa semakin baik kualitas desentralisasi fiskal, maka akan semakin baik kinerja keuangan daerah yang ditunjukkan oleh meningkatnya indikator rasio kemandirian, rasio efektivitas, upaya fiskal dan pertumbuhan pendapatan daerah.

Hasil temuan ini mendukung hasil penelitian sebelumnya Syahrudin, 2006; Siddik, 2002; Fontanella dan Rossieta, 2014; Lay, 2001; Kurniasih, 2011; dan Mursinto, 2004 dimana desentralisasi fiskal mampu meningkatkan kinerja keuangan daerah. Berdasarkan hasil analisis dapat diketahui bahwa koefisien seluruh indikator pada desentralisasi fiskal menunjukkan positif dan signifikan, yang berarti keseluruhan indikator 
memberikan pengaruh terhadap kinerja keuangan. Namun pengaruhnya berasal dari bantuan pemerintah pusat dalam bentuk dana perimbangan masih mendominasi sumber penerimaan daerah dibandingkan dengan sumber yang berasal dari pendapatan riil daerah seperti PAD. Hal ini dapat diketahui uji kontribusi yang dilakukan selama periode penelitian dari Tahun 2008 - 2017 menemukan bukti bahwa mayoritas pengelolaan keuangan daerah sumber dananya berasal dari dana perimbangan pemerintah pusat yang mencapai 80,6 persen dari total penerimaan daerah yang digunakan untuk membiayai pembangunan, sementara PAD hanya memberikan kontribusi 8,4 persen dari total penerimaan daerah.

\section{Pengaruh Desentralisasi Fiskal dan Kinerja Keuangan Terhadap Kinerja Ekonomi}

Hasil analisis menunjukkan bahwa desentralisasi fiskal dan kinerja keuangan berpengaruh positif dan signifikan terhadap kinerja ekonomi. Hal ini berarti semakin baik kualitas desentralisasi fiskal dan pengelolaan keuangan daerah, maka semakin baik pula kinerja ekonomi daerah. Temuan ini membuktikan adanya hubungan searah antara desentralisasi fiskal dan kinerja keuangan terhadap kinerja ekonomi. Hasil studi ini mendukung pandangan yang pro desentralisasi fiskal seperti Tanzi, 1996, Litvack et al. 1998, Tiebout, 1956, Oates, 1972, Tresch,198, Breton, 1996, Weingast, 1995, Akai dan Sakata, 2002, Thiessen, 2003, dan Desai et al. 2003. dimana desentralisasi fiskal berpengaruh signifikan terhadap kinerja ekonomi.

Adanya hubungan yang Positif dan signifikan dari variabel desentralisasi fiskal dan kinerja keuangan terhadap kinerja ekonomi disebabkan karena adanya peran penting dari belanja daerah sebagai sumber pembiayaan pembangunan. Belanja daerah merupakan komponen utama pemerintah daerah dalam membiayai pembangunan. Belanja daerah yang terdiri dari belanja langsung dan tidak langsung merupakan komponen pengeluaran daerah yang sudah pasti terjadi karena bersifat untuk pendanaan kegiatan rutin terutama untuk aparatur daerah pada daerah yang bersangkutan, misalnya belanja modal untuk membiayai pembangunan, membayar gaji pegawai negeri dan honorarium sebagai kompensasi bagi pegawai negeri terhadap aktivitas kegiatan yang dilakukan di daerah. Penerimaan gaji pegawai negeri dan honorarium di daerah yang bersangkutan oleh pegawai negeri akan menjadi faktor pendapatan yang akan digunakan untuk kegiatan konsumsi membeli barang dan jasa yang dibutuhkan pegawai negeri tersebut. Oleh karena itu, kegiatan membeli barang dan jasa akan menimbulkan permintaaan barang dan jasa yang akan direspon oleh produsen/para pengusaha untuk menghasilkan barang dan jasa sesuai dengan kebutuhan konsumen, sehingga akan terjadi aktivitas ekonomi.

\section{Pengaruh Desentralisasi Fiskal, Kinerja Keuangan dan Kinerja Ekonomi Terhadap Ketimpangan Pendapatan}

Hasil penelitian menunjukkan bahwa desentralisasi fiskal berpengaruh negatif dan tidak signifikan terhadap ketimpangan pendapatan. Hasil ini menolak hipotesis ketiga yang diajukan bahwa desentralisasi fiskal berpengaruh negatif dan signifikan terhadap ketimpangan pendapatan. Dalam penelitian ini indikator desentralisasi fiskal yang terdiri indikator pengeluaran, indikator pendapatan dan derajat otonomi tidak berpengaruh signifikan terhadap ketimpangan pendapatan yang terdiri dari indikator indeks Williamson, indeks Entropi Theil dan indeks Jamie Bonet. Hal tersebut membuktikan bahwa desentralisasi fiskal belum mampu menurunkan ketimpangan pendapatan di Kabupaten/Kota di Provinsi Nusa Tenggara Barat.

Hasil temuan ini mendukung penelitian Nugrahanto \& Muhyiddin (2008) dalam Nurhaemi dan Suryani (2015) yang mengkaji secara empiris dampak desentralisasi fiskal dengan ketimpangan wilayah di Indonesia. Pandangan konvensional menyatakan bahwa desentralisasi fiskal meningkatkan ketimpangan wilayah karena tekanan dari pemerintah pusat untuk redistribusi pendapatan antara daerah menjadi lebih 
rendah setelah desentralisasi fiskal. Di sisi lain, desentralisasi fiskal mendorong upaya peningkatan pendapatan asli daerah (PAD) untuk membiayai pengeluaran daerah, sehingga tidak tergantung pada hibah dari pemerintah pusat. Hasil penelitian menunjukkan ketika desentralisasi fiskal meningkat, maka ketimpangan pendapatan pun ikut meningkat. Tidak signifikannya peranan desentralisasi fiskal mengurangi ketimpangan pendapatan disebabkan oleh masih terbatasnya sumber-sumber penerimaan daerah (PAD) terutama yang berasal dari pajak daerah dan retribusi daerah sehingga pemerintah daerah memiliki keterbatasan memprioritaskan skala pembangunan yang ditetapkan. Keberhasilan pelaksanaan otonomi daerah melalui desentralisasi fiskal di ukur dengan melihat besarnya PAD yang peroleh. Semakin tinggi PAD maka kemampuan daerah membiayai pembangunan akan semakin tinggi. Demikian pula sebaliknya semakin rendah PAD maka semakin rendah pula kemampuan daerah membiayai pembangunan daerahnya. Untuk membuktikan rendahnya PAD peneliti menggunakan uji kontribusi dengan membandingkan PAD dengan penerimaan daerah.

Berdasarkan uji kontribusi PAD terhadap total penerimaan daerah selama periode penelitian dari 2018 - 2017 ditemukan bukti kontribusi PAD di Provinsi Nusa Tenggara Barat hanya mencapai 8,6 persen dari total pendapatan daerah. Hal ini menunjukkan kemampuan daerah membiayai pembangunan berdasarkan sumber asli penerimaan daerah masih rendah. hasil penelitian ini sesuai dengan teori hipotesis $U$ terbalik dari Kuznets dimana pada tahap awal pembangunan ketimpangan pendapatan semakin memburuk. Menurut Tarigan (2004) desentralisasi fiskal yang rendah di masingmasing daerah secara bertahap akan menurunkan pemerataan antar wilayah/menambah ketimpangan. Hal ini dapat dijelaskan dengan teori kutub pertumbuhan yaitu semakin sedikit kutub pertumbuhan dalam suatu daerah maka akan semakin tidak rata distribusi pendapatan daerah tersebut, walaupun daerah-daerah kumuh (slum) akan muncul. Tetapi lambat laun daerah ini akan berkurang seiring dengan munculnya kutub-kutub pertumbuhan ekonomi yang baru.I

Pengaruh Desentralisasi Fiskal, Kinerja Keuangan, Kinerja ekonomi dan Ketimpangan Pendapatan Terhadap Kesejahteraan Masyarakat

Berdasarkan hasil penelitian diperoleh temuan bahwa desentralisasi fiskal berpengaruh negatif dan signifikan terhadap kesejahteraan masyarakat. Hasil penelitian ini menolak hipotesis keempat yaitu desentralisasi fiskal berpengaruh positif dan signifikan terhadap kesejahteraan masyarakat. Hal ini berarti semakin baik kualitas desentralisasi fiskal justru kesejahteraan masyarakat menurun.

Hasil temuan ini mendukung penelitian Suryanto dkk (2005) bahwa desentralisasi fiskal belum banyak bermanfaat bagi peningkatan kesejahteraan masyarakat. Hasil yang sama juga ditunjukkan oleh penelitian Faridli (2011) bahwa pemerintah pusat seharusnya mendelegasikan kekuatan fiskalnya kepada pemerintah Provinsi dan Pemerintah Kabupaten/Kota untuk meningkatkan kesejahteraan hidup masyarakat di Pakistan.

Adanya hubungan negatif ini tentu memberikan dampak yang tidak baik bagi kesejahteraan masyarakat dimana respon masyarakat terhadap kualitas desentralisasi fiskal yang dikelola oleh pemerintah daerah tidak meningkatkan kesejahteraan masyarakat. Berdasarkan hasil penelitian selama periode tahun 2008 - 2017 ditemukan bukti bahwa pelaksanan desentralisasi fiskal di Provinsi Nusa Tenggara Barat menunjukkan daerah belum mampu memberikan kesejahteraan bagi masyarakatnya. Hal ini dapat diketahui dari beberapa faktor pendukung antara lain masih rendahnya sumber-sumber penerimaan asli masing-masing daerah (PAD) sebagai alat ukur kemandirian daerah. Berdasarkan uji Kontribusi PAD terhadap total pendapatan daerah ditemukan kontribusi PAD hanya mencapai 8,6 persen per tahun. Hal ini menunjukkan anggaran yang tersedia untuk membiayai program pembangunan daerah 
tidak sesuai dengan rencana pembangunan yang telah di susun pada masing-masing Kabupaten/Kota sehingga pelayanan terhadap masyarakat seperti pelayanan kesehatan, pendidikan, pendapatan yang layak tidak dapat dilakukan secara optimal. Faktor selanjutnya adalah sering kali Regulasiregulasi yang dibuat pemerintah provinsi tidak sesuai dengan keinginan pemerintah daerah. Misalnya perda daerah mengenai larangan penggalian bahan tambang tapi bagi beberapa daerah malah memberikan izin penambangan.

\section{Pengaruh Desentralisasi Fiskal Terhadap Kinerja Ekonomi Melalui Kinerja Keuangan}

Hasil penelitian menunjukkan bahwa secara tidak langsung desentralisasi fiskal berpengaruh signifikan terhadap kinerja ekonomi melalui kinerja keuangan Hasil penelitian ini mendukung hipotesis yang diajukan bahwa ada pengaruh tidak langsung desentralisasi fiskal terhadap kinerja ekonomi melalui kinerja keuangan. Hasil temuan ini membuktikan bahwa kinerja keuangan sebagai variabel perantara memiliki peran penting mempengaruhi kinerja ekonomi. Hasil temuan ini sejalan dengan hasil penelitian Hamzah (2007), Ronald dan Sarmiyatiningsih (2010) menemukan bukti kinerja keuangan melalui rasio kemandirian dan rasio efisiensi berpengaruh signifikan terhadap kinerja ekonomi melalui pertumbuhan ekonomi. Semakin besar desentralisasi fiskal daerah maka semakin besar pula kemampuan daerah mengelola keuangan daerahnya.

Salah satu faktor penting yang mempengaruhi keberhasilan pelaksanaan pembangunan daerah adalah kemampuan keuangan daerah yang memadai. Semakin besar keuangan daerah, maka semakin besar kemampuan daerah membiayai pembangunan daerah. Menurut Djokroamidjojo (1993) pemerintah daerah akan dapat menjalankan fungsinya dalam rangka otonomi atau desentralisasi secara baik bila diterima sumber-sumber keuangan yang cukup untuk membiayai fungsi tersebut. Sumber-sumber keuangan di Provinsi Nusa Tenggara Barat selama periode penelitian masih didominasi oleh bantuan/transfer pemerintah pusat serta PAD. Sumber keuangan ini kemudian digunakan oleh pemerintah daerah membiayai pembangunan melalui belanja daerah yang telah direncanakan sebelumnya. Belanja daerah selanjutnya direspon oleh para pengusaha dengan menciptakan barang dan jasa yang dibutuhkan pemerintah. Produksi barang dan jasa ini akan menciptakan PDRB yang secara keseluruhan akan meningkatkan kinerja ekonomi daerah.

Pengaruh Desentralisasi Fiskal Terhadap Ketimpangan Pendapatan Melalui Kinerja Keuangan dan Kinerja Ekonomi

Hasil penelitian menunjukkan bahwa secara tidak langsung desentralisasi fiskal berpengaruh signifikan terhadap ketimpangan pendapatan melalui kinerja keuangan dan kinerja ekonomi. Hasil penelitian ini mendukung hipotesis keenam yang diajukan bahwa ada pengaruh tidak langsung desentralisasi fiskal terhadap ketimpangan pendapatan melalui kinerja keuangan dan kinerja ekonomi. Hasil temuan ini membuktikan bahwa kinerja keuangan dan kinerja ekonomi sebagai variabel perantara memiliki peran penting mempengaruhi ketimpangan pendapatan di Provinsi Nusa Tenggara Barat.

Desentralisasi fiskal dikatakan berhasil apabila daerah mampu menggali sumber-sumber penerimaan daerah. Sumbersumber penerimaan daerah ini dimanfaatkan oleh pemerintah utuk membiayai pembangunan melalui pengelolaan keuangan yang efektif, efisien dan memiliki kemadirian yang tinggi. Pengelolaan keuangan selanjutnya digunakan membiayai pembangunan melalui belanja daerah yang telah direncanakan. Dengan adanya belanja daerah ini akan mendorong kenaikan aktivitas ekonomi. Semakin tinggi aktivitas ekonomi maka akan mengurangi ketimpangan pendapatan yang terjadi masyarakat.

Pengaruh Kinerja Keuangan Terhadap Ketimpangan Pendapatan Melalui Kinerja Ekonomi

Hasil penelitian menunjukkan bahwa secara tidak langsung kinerja keuangan berpengaruh tidak signifikan terhadap ketimpangan pendapatan melalui kinerja 
ekonomi. Hasil penelitian ini tidak mendukung hipotesis ke tujuh yang diajukan bahwa ada pengaruh tidak langsung kinerja keuangan terhadap ketimpangan pendapatan melalui kinerja ekonomi. Hasil temuan ini membuktikan bahwa kinerja ekonomi sebagai variabel perantara tidak memiliki peran penting mempengaruhi ketimpangan pendapatan. Hasil temuan ini tidak sejalan dengan penelitian Shahbaz (2011) menemukan bahwa kinerja keuangan secara tidak langsung mampu mengurangi ketimpangan pendapatan melalui pertumbuhan ekonomi di Pakistan. Tidak signifikannya kinerja keuangan mempengaruhi ketimpangan pendapatan melalui kinerja ekonomi dikarenakan Provinsi Nusa Tenggara Barat masih pada tahap awal pembangunan ekonomi. Pada tahap awal pembangunan ekonomi, ketimpangan ekonomi antar masyarakat akan terus terjadi. Hal ini sesuai dengan teori hipotesis $U$ terbalik yang dikemukakan oleh Kuznets bahwa pada awal pembangunan ekonomi ketimpangan akan terjadi dimana-mana dan apabila pembangunan ekonomi terus menerus dilakukan maka pada suatu titik ketimpangan pendapatan antar masyarakat akan menurun sehingga terjadi pemerataan distribusi pendapatan di masyarakat.

\section{Pengaruh Desentralisasi Fiskal Terhadap} Kesejahteraan Masyarakat Melalui Kinerja Keuangan, Kinerja Ekonomi dan Ketimpangan Pendapatan

Hasil penelitian menunjukkan bahwa secara tidak langsung desentralisasi fiskal berpengaruh signifikan terhadap kesejahteraan masyarakat melalui kinerja keuangan, kinerja ekonomi dan ketimpangan pendapatan. Hasil penelitian ini mendukung hipotesis yang diajukan bahwa ada pengaruh tidak langsung desentralisasi fiskal terhadap kesejahteraan masyarakat melalui kinerja keuangan, kinerja ekonomi dan ketimpangan pendapatan. Hasil temuan ini membuktikan bahwa kinerja keuangan, kinerja ekonomi dan ketimpangan pendapatan di Provinsi Nusa Tenggara Barat sebagai variabel perantara memiliki peran penting mempengaruhi kesejahteraan masyarakat. Hasil temuan ini sejalan dengan penelitian yang dilakukan oleh
Ganie dkk, 2019; Nangoli dkk, 2015; Fictoria, 2018 dan Sossberg, 2017 menemukan pentingnya peranan kinerja keuangan dan ketimpangan pendapatan dalam meningkatkan kesejahteraan masyarakat.

Desentralisasi yang semakin baik direflesikan dengan kemampuan pemerintah daerah menggali potensi sumber daya yang di miliki. Semakin besar sumber-sumber penerimaan daerah (PAD), maka semakin besar pula kemampuan pemerintah dalam mengelola keuangan daerahnya. Dengan kemampuan yang besar berarti komponen belanja daerah seperti belanja modal semakin tinggi dan semakin banyak program pembangunan ekonomi yang bisa dilakukan pemerintah daerah dalam meningkatkan kesejahteraan masyarakatnya. Selain itu, semakin besar kemampuan daerah mengelola keuangannya melalui meningkatnya program pembangunan tentu juga direspon oleh para pengusaha dengan menciptakan barang dan jasa yang dibutuhkan pemerintah. Proses menciptakan barang ini secara langsung akan membentuk PDB yang nilainya akan terus bertambah yang pada akhirnya meningkatkan kinerja ekonomi daerah dimana pengangguran menurun, investasi swasta akan meningkat dan jumlah penduduk yang berada diatas garis kemiskinan akan meningkat. Meningkatnya kinerja ekonomi tentu juga akan menambah pusat-pusat terbentuknya daerah pertumbuhan ekonomi baru yang selanjutnya akan menimbulkan distribusi pendapatan yang semakin merata di Kabupaten/Kota di Provinsi Nusa Tenggara Barat.

\section{Pengaruh Kinerja Keuangan Terhadap kesejahteraan Masyarakat Melalui Kinerja Ekonomi dan Ketimpangan Pendapatan.}

Hasil penelitian menunjukkan bahwa secara tidak langsung kinerja keuangan daerah berpengaruh signifikan terhadap kesejahteraan masyarakat melalui kinerja ekonomi dan ketimpangan pendapatan Hasil penelitian ini mendukung hipotesis yang diajukan bahwa ada pengaruh tidak langsung kinerja keuangan terhadap kesejahteraan masyarakat melalui kinerja ekonomi dan ketimpangan pendapatan. Hasil temuan ini membuktikan bahwa kinerja ekonomi dan ketimpangan pendapatan sebagai variabel 
perantara memiliki peran penting mempengaruhi kesejahteraan masyarakat di Provinsi Nusa Tenggara Barat.

Kinerja keuangan akan semakin efektif dan efisien mempengaruhi kesejahteraan masyarakat apabila kinerja ekonomi dan pemerataan pendapatan meningkat. Semakin efektif dan efisien pengelolaan keuangan daerah, maka semakin besar pula kemampuan pemerintah dalam mengelola keuangan daerahnya. Dengan kemampuan mengelola keuangan yang besar akan meningkatkan kinerja ekonomi yang diwujudkan melalui penurunan angka pengangguran, meningkatnya pendapatan perkapita masyarakat akibat dari bertambahnya investasi swasta dan bertambahnya jumlah penduduk yang berada di atas garis kemiskinan. Selanjutnya, dengan semakin meningkatnya kinerja ekonomi akan membentuk pusat-pusat pertumbuhan ekonomi baru yang selanjutnya akan menurunkan ketimpangan pendapatan antar daerah yang pada akhirnya menciptakan kesejahteraan masyarakat.

\section{Pengaruh Kinerja Ekonomi Terhadap kesejahteraan Masyarakat Melalui Ketimpangan Pendapatan.}

Hasil penelitian ini menunjukkan bahwa kinerja ekonomi berpengaruh tidak signifikan terhadap kesejahteraan masyarakat melalui ketimpangan pendapatan. Dengan demikian, kinerja ekonomi yang diukur menggunakan indikator penyerapan tenaga kerja, pendapatan perkapita, investasi swasta, dan PDRB per-kapita tidak mampu menjelaskan dengan baik secara tidak langsung perkembangan kesejahteraan masyarakat yang diukur menggunakan angka harapan hidup, harapan lama sekolah, ratarata lama sekolah dan pengeluaran perkapita. Hasil penelitian ini tidak mendukung hipotesis kesepuluh yaitu kinerja ekonomi berpengaruh positif dan signifikan terhadap kesejahteraan masyarakat melalui ketimpangan pendapatan. Tidak signifikannya kinerja ekonomi terhadap kesejahteraan masyarakat melalui ketimpangan pendapatan lebih disebabkan oleh faktor tidak inklusifnya pertumbuhan ekonomi yang terjadi di Provinsi Nusa Tenggara Barat.

\section{Simpulan}

1. Desentralisasi fiskal berpengaruh positif dan signifikan terhadap kinerja keuangan daerah.

2. Desentralisasi fiskal dan kinerja keuangan berpengaruh positif dan signifikan terhadap kinerja ekonomi.

3. Desentralisasi fiskal berpengaruh negatif dan tidak signifikan terhadap ketimpangan pendapatan, kinerja keuangan dan kinerja ekonomi berpengaruh positif dan signifikan terhadap ketimpangan pendapatan.

4. Desentralisasi fiskal berpengaruh positif dan tidak signifikan terhadap kesejahteraan masyarakat. Kinerja keuangan, kinerja ekonomi dan ketimpangan pendapatan berpengaruh positif dan signifikan terhadap kesejahteraan masyarakat.

5. Desentralisasi fiskal berpengaruh positif dan signifikan terhadap kinerja ekonomi melalui kinerja keuangan.

6. Desentralisasi fiskal berpengaruh positif dan signifikan terhadap ketimpangan pendapatan melalui kinerja ekonomi.

7. Kinerja keuangan berpengaruh positif dan tidak signifikan terhadap ketimpangan pendapatan melalui kinerja ekonomi.

8. Desentralisasi fiskal berpengaruh positif dan signifikan terhadap kesejahteraan masyarakat melalui kinerja keuangan, kinerja ekonomi dan ketimpangan pendapatan.

9. Kinerja keuangan berpengaruh positif dan signifikan terhadap kesejahteraan masyarakat melalui kinerja ekonomi dan ketimpangan pendapatan.

10. Kinerja ekonomi berpengaruh positif dan tidak signifikan terhadap kesejahteraan masyarakat melalui ketimpangan pendapatan.

\section{Saran}

1. Pemerintah daerah sebaiknya berfokus pada peningkatan sumber penerimaan daerah (PAD) dengan jalan meningkatkan entrepreneurship usaha milik pemerintah dengan meningkatkan SDM, memperbaiki sistem dan membuka akses seluas-luasnya; 
mempermudah izin usaha pada semua sektor dan mendorong semangat masyarakat untuk berwiraswasta. Harapan tersebut dapat memperoleh pendapatan melalui pajak dan retribusi.

2. Dalam upaya meningkatkan kinerja keuangan sangat penting bagi pemerintah untuk menetapkan ukuran keberhasilan PAD tidak hanya dari jumlah yang dapat dipungut atau diterima, namun juga dari perannya dalam mengatur perekonomian masyarakat sehingga dapat meningkatkan kesejahteraan masyarakat.

3. Untuk menurunkan ketimpangan pendapatan hendaknya didorong melalui pertumbuhan ekonomi yang inklusif serta penguatan lembaga - lembaga sosial masyarakat.

4. Dalam upaya mempercepat kesejahteraan masyarakat, sangat penting bagi pemerintah daerah Provinsi Nusa Tenggara Barat untuk memberikan perhatian pada peningkatan angka harapan hidup, harapan lama sekolah, rata-rata lama sekolah dan pengeluaran per-kapita.

\section{DAFTAR PUSTAKA}

Akai, Nobuo, \& Sakata, Masayo. (2002). Fiscal Decentralization Contributes To Economic Growth: Evidence From State-Level Cross-Section Data For The United States. Journal Of Urban Economics 52 (2002) 93-108.

Akai, \& Sakata. 2005. Fiscal Decentralization, Commitment and Regional Inequality: Evidence Fromstate Level Cross-Sectional Data For The United States. Osaka: Osaka International University.

Arsyad, Lincoln. 2004. Ekonomi Pembangunan, UPP YPKN, Yogyakarta.

Badan Pusat Statistik. 2009. PDRB Propinsi Nusa Tenggara Barat Menurut Kabupaten/Kota. Badan Pusat Statistik Propinsi Nusa Tenggara Barat. Mataram.

Badan Pusat Statistik. 2018. Indeks Pembangunan Manusia 2008 2017. BPS, Nusa Tenggara Barat.
Badan Pusat Statistik. 2014. NTB Dalam Angka. Katalog BPS 1102001.52 Mataram: BPS Nusa Tenggara Barat. 2016. NTB Dalam Angka. Katalog BPS 1102001.52 Mataram: BPS Nusa Tenggara Barat.

Angka. Katalog BPS 1102001.52 Mataram: BPS Nusa Tenggara Barat.

Bahl, R. W. \& Linh, J. 1992. Urban finance in development countries. New York: Oxford University Press.

Bahl, Roy W. 1999. "China: Evaluating the Impact of Intergovernmental Fiscal Reform," Fiscal Decentralization in Developing Countries.

Baskaran, T., \& Feld, P Lars. 2009. Fiscal Decentralization and Economic Growth in OECD Countries: Is there a Relationship? Cesifo Working Paper No. 2721.

Baskaran, et all. 2014. Fiscal Federalism, Decentralization and Economic Growth: Survey and meta-analysis CESifo Working Paper (2014), p. 4985.

Bird, Richard M., 1990. Intergovernmental Finance and Local Taxation in Developing Countries Some Basic Consideration for Reformers. Public Administration and Development.

Bird, Richard M. 1993. "Threading the Fiscal Labyrinth: Some Issues in Fiscal Decentralization". National Tax Journal 46 (3): 207-227.

Davoodi, H., \& Zou, Heng-fu. (1998). Fiscal Decentralization and Economic Growth: A Cross-Country Study. Journal of Urban Economics, 43:244-57.

Elmi, B. 2002. Keuangan Pemerintah Daerah Otonom di Indonesia. Penerbit Universitas Indonesia (UIPress), Jakarta.

Galbraith, James K., and Hyunsub Kum. 2012. Inequality and Economic Growth: Data Comparisons and Econometric Tests. UTIP Working Paper Number 21.

Gramlich, E. 1993. "A Policy Maker's Guide To Fiscal Decentralization". 
National Tax Journal XLVI, 229235

Halim, Abdul. 2001. Bunga Rampai Menejemen Keuangan Daerah. Yogyakarta: Unit Penerbit dan Percetakan.

Halim, Abdul. 2007. Akuntansi Sektor Publik-Akuntansi Keuangan Daerah. Jakarta: Salemba Empat.

Halim, Abdul dan Jamal A Nasir. 2006. "Kajian Tentang Keuangan Daerah Pemerintah Kota Malang". Majalah Manajemen Usahawan Indonesia. No. 06/TH XXXV.

Halim, Abdul. 2004. Manajemen Keuangan Daerah. Penerbit UPP Akademi Manajemen Perusahaan YKPN. Yogyakarta.

Indriani. 2011. Pengaruh Pengeluaran Konsumsi dan Investasi Pemerintah terhadap Pertumbuhan Ekonomi di Indonesia. Jurnal. Diakses dari http://www.econosains.com/index. pada tanggal 07 April 2016 pukul 11.27 WIB.

Iriani, Dewi. 2015. Pengaruh Desentralisasi Fiskal Terhadap Pertumbuhan Ekonomi Dan Kesejahteraan Masyarakat DI Provinsi Papua Tahun 1997-2013. Other thesis, UPN "Veteran" Yogyakarta.

Iswanto. 2015. Ketimpangan Pendapatan Antar Kabupaten/Kota dan Pertumbuhan Ekonomi Di Provinsi Jawa Timur. Vol. 4 No. 1 April 2015.

Jhingan, ML. 1999. Ekonomi Perencanaan dan Pembangunan. Jakarta: Rajawali Pers.

Kuncoro, Mudrajad. 2003. Otonomi dan Pembangunan Daerah: Reformasi, Strategi, Perencanaan dan Peluang. Jakarta: Erlangga.

Kuncoro, Mudrajad. 2004. Ekonomika Pembangunan: Teori, Masalah, dan Kebijakan, UPP Akademi Manajemen Perusahaan YKPN.

Kuncoro, Mudrajad. 2013. Metode Riset Untuk Ekonomi dan Bisnis. Jakarta: Erlangga.
Kuncoro, Sri. 2014. Analisis Pengaruh Pertumbuhan Ekonomi, Tingkat Pengangguran dan Pendidikan Terhadap Tingkat Kemiskinan di Provinsi Jawa Timur Tahun 20092011.

Kuznets, Simon. 1955. Economic Growth and Income Inequality. The American Economic Review, 45(1): 1-28.

Kuznet, Simon. 1995. Quantitative Aspec of the Economic Growth of Nation : I. Economic Development and Cultiral Change, Vol. V.

Mankiw, N. Gregory. (2003), Macroeconomics. 4th ed. New York: Worth Publisher.

Mankiw, N. Gregory. 2006. Macroeconomics, $4^{\text {th }}$ Edition, Worth Publisher, Madison, Avenue, New York.

Mardiasmo. 2001. Budgeting Management Structure in Decentralization Era. Workshop Paper SIAGA Project. Yogyakarta: STIE.

Mardiasmo. 2002. Otonomi dan Manajemen Keuangan daerah. Penerbit : Andi, Yogyakarta.

Mardiasmo. 2009. Kebijakan Desentralisasi Fiskal di Era Reformasi: 2005 2008. Dalam Abimanyu, Anggito \& Megantara, Andie. Era Baru Kebijakan Fiskal: Pemikiran, Konsep dan Implementasi. Jakarta: Penerbit Kompas.

McEachern, William, A, 2000, Ekonomi Makro Pendekatan Kontenporer, Terjemahan, Sigit Triandaru, Salemba Empat, Jakarta.

McKinnon. 1997. Market Preserving Fiscal Federalism in The American Monetary Union dalam Vito Tanzi ed. Macroeconomic Dimensions of Public Finance: Essays in Honour of Vito Tanzi. Vol 36, Routledge, London.

Mydrall, G. 1957. Economic Theory and Underdeveloped Region. Methuen London.

Oates, Wallace E. 1972. Fiscal Federalism. Harcourt Brace Jovanovich. 
Oates, Wallace E. 1993. Fiscal Decentralization and Economic Development. National Tax Journal Vol. 46 No. 2 (June, 1993) 237-243.

Raswita dan Utama. 2013. Analisis Pertumbuhan Ekonomi dan Ketimpangan Pendapatan Antar Kecamatan Di Kabupaten Gianyar 2013. E-Jurnal EP Unud, 2 [3] : $119-128$

Samuelson, Paul A, dan Nordhaus. 1995. Pembangunan Ekonomi (edisi terjemahan). Edisi ke-12. Jakarta: Erlangga.

Ter-Minassian, Teresa. 1997. Fiscal Federalism in Theory and Practice. Washington, International Monetary Fund.

Thiessen, Ulrich. 2003. Fiscal Decentralization and Economic Growth in High Income OECD Countries. Fiscal Studies Vol. 24 No. 3.

Thresch, Richard W. 1981. Public Finance: A Normative Theory. California: Academic Press.

Tjokroamidjojo. 1994, Dasar Ekonomi Pertumbuhan dan Ekonomi Pembangunan, LP3ES, Jakarta.

Tiebout, Charles M. 1956. A pure theory of local expenditures. The Journal of Political Economy, 64/ 5 (October 1956 ), 416 - 424. The University of Chicago Press.

Todaro, Michael, P. 2003. Pembangunan Ekonomi di Dunia Ketiga. Erlangga, Jakarta.

Todaro, Michael, P., 1997. Pembangunan Ekonomi di Dunia Ketiga. Alih Bahasa Indonesia: Burhanudin Abdullah dan Harris Munandar.

Todaro, Michael, P. 2004. Pembangunan Ekonomi Di Dunia Ketiga. Edisi Kedelapan. Jakarta: Erlangga.

Todaro, Michael P. And Smith Stephen C., 2003, Economic Development, Eighth Edition, United Kingdom : Pearson Education Limited.

Todaro, M. P dan Smith S.C, 2004, Pembangunan Ekonomi di Dunia
Ketiga, Alih Bahasa Harris Munandar dan Puji A.L, Erlangga Jakarta.

Todaro, Michael P., \& Smith Stephen C. 2006. Pembangunan Ekonomi (Yelvi Andri, Penerjemah), Edisi 9. Jakarta: Penerbit Erlangga.

Thresch, Richard W. 1981. Public Finance: A Normative Theory. California: Academic Press.

Verbeek, Baltagi. 2008.. Econometric Analysis of Panel data, John Wiley $\&$ Sons, LTD, New York.

Waluyo, Joko. 2007. Dampak Desentralisasi Fiskal Terhadap Pertumbuhan dan Aplikasi Untuk Ekonomi dan Bisnis. Yogyakarta: Penerbit EKONISIA.

Wei, Y Dennis., dan Fan C Cindy. (2000). Regional Inequality in China: a Case Study of Jiangsu Province. Asian Economic Journal. Vol. 52, 455-469.

Weingast. 1995. The economic role of political institutions: Market Preserving federalism and economic development. Journal of Law, Economics, and Organization, $11,1-31$.

Wetzels. 2002. Using Pls Path Modeling for Assessing Hierarchicalconstruct Models: Guidelines and Empirical illustration. MIS Quarterly Vol. 33 No. 1.

World Bank, 1997. On Line Source Book on Decentralization and Rural Development, Decentralization Thematic Team, SDA.

Williamson, J. G. 1965. Regional Inequality and The Process of National Development: A Description of The Patterns. Economic Development and Cultural Change, 13 (4), 1-84.

Williamson, J. G. 1997. Regional and Equity and the Process of National Development; A Description of Patern Economics and Cultural Change, Vol. 13, No. 4: 3-45. Work. 2002. Overview of decentralization worldwide: A stepping stone to improved governance and human 
development. Manila 2nd

International Conference on

Decentralization.

Wulandari. 2001. Kemampuan Keuangan Daerah di Kota Jambi Dalam Melaksanakan Otonomi Daerah. Jurnal Kebijakan dan Administrasi Publik, Kemampuan Keuangan Daerah (Vol. 5, No. 2). November.

Xie, D., Zou, H., \& Davoodi, H. 1998. Fiscal Decentralization and Economic Growth in the United States. Journal of Urban Economics, 45: 228-239.

Yamoah, Afia Boadiwaa. 2007. The Effects Of Fiscal Decentralization On Economic Growth In U.S. Counties. Dessertation, The Ohio State University.

Zhang Tao, \& Zou Heng-Fu. 1998. Fiscal Decentralization. Public Spending and Economic Growth in China. Journal of Public Expenditure, 67: 221- 240. 